\title{
Producing randomness between plots in pepper and snap bean experiments
}

\section{Aleatoriedade da produção entre parcelas em experimentos de pimentão e feijão-de-vagem}

\author{
Vilson Benz ${ }^{1 *}$; Alessandro Dal'Col Lúcio ${ }^{2}$
}

\begin{abstract}
It is important to know the production variability among experimental plots in a protected environment because this information reduces error and increases the reliability of the results. Therefore, the objective of this study was to characterize the spatial independence of fruit yield between plots of peppers and snap beans. Data on production uniformity were gathered from trials performed at the Department of Plant Science, Federal University of Santa Maria. Different plots sizes were created according to the number of plants in the crop row. To verify the randomness of the data distribution, we applied a sequence test between the plots within one line for individual and combined harvests. The use of ten plants per plot in experiments with peppers led to no randomness within the lines during the production of fruit fresh biomass. In experiments with snap beans conducted in a greenhouse, a plastic tunnel and by unprotected cultivation using plots with six or more basic units, 12 or more plants per plot produced random fresh biomass data for fruits within the crop row.
\end{abstract}

Key words: Capsicum annuum. Phaseolus vulgaris L. Run test. Experimental planning. Experimental precision.

\section{Resumo}

O conhecimento da variabilidade da produção entre as parcelas experimentais no ambiente protegido se faz necessário, pois possibilita a redução do erro aumentando a confiabilidade nos resultados. Assim sendo, o objetivo deste estudo foi caracterizar a independência espacial das produções de frutos entre parcelas de pimentão e feijão-de-vagem. Foram utilizados dados de produção de ensaios de uniformidade realizados no Departamento de Fitotecnia da Universidade Federal de Santa Maria. Com os valores da produção individual foram simulados diferentes tamanhos de parcelas conforme o número de plantas na linha de cultivo. Para verificar a aleatoriedade da distribuição dos dados, foi aplicado o teste de sequências entre parcelas dentro da linha em colheitas individuais e agrupadas. O uso de dez plantas por parcela em experimentos com pimentão é suficiente para que não haja linhas com falta de aleatoriedade da produção de fitomassa fresca de frutos. Em experimentos com feijão-de-vagem conduzidos em estufa plástica, túnel plástico e cultivo não protegido o uso de parcelas com seis ou mais unidades básicas, 12 ou mais plantas por parcela, torna aleatória a produção de fitomassa fresca de frutos dentro das linhas de cultivo.

Palavras-chave: Capsicum annuum. Phaseolus vulgaris L. Teste de sequências. Planejamento experimental. Precisão experimental.

${ }^{1}$ Eng $^{\mathrm{o}} \mathrm{Agr}^{\mathrm{o}}$, Dr., Colégio Politécnico da UFSM, Universidade Federal de Santa Maria, UFSM, Santa Maria, RS, Brasil. E-mail: vibenz@gmail.com

2 Prof. Dr., Departamento de Fitotecnia, UFSM, Santa Maria, RS, Brasil. E-mail: adlucio@ufsm.br

* Author for correspondence 


\section{Introduction}

Over the past decade, the production of vegetables in Brazil has increased 33\% while the cultivation area has fallen by $5 \%$ and productivity has risen $38 \%$. Approximately three quarters of production is concentrated in the south and southeast regions, whereas the northeast and central-west account for $25 \%$ of total production (MELO; VILELA, 2007).

These indicators of increase in productivity, even with the reduction in the cultivation area, reflect the application of results obtained from studies on vegetables, where experimental performance needs to be consistent. However careful the planning and execution of these experiments, there are always random variations between the plots within the same treatment. This is called experimental error (STEEL et al., 1997). It is known that plant production is influenced by many factors that may cause data variability in the experimental units planted in crop rows and, if the variability is not random, the experimental error increases and the assumptions of mathematical models are not satisfied. This situation occurs in crops with multiple harvests where harvest differences in the same experimental unit may not be random, or different plots in a crop row behave differently in each harvest. Zanardo et al. (2010) identified variations in the soil nutrient concentration, differences caused by management practices, and the location of plants in the plots as some of the causes. According to Lorentz et al. (2005) and Facco et al. (2015), there have been few studies on the existing variations between plants in the same crop row and those that exist are frequently disregarded, causing misconceptions in the planning of plot allocations in an experimental area.

Plants cultivated in plastic greenhouses are susceptible to spatial variability due to the variation in air temperature between plants near the vents (entry doors, side curtains) and those placed at the center of the plastic greenhouse. These aspects, among others, are inherent to the plastic greenhouse structure, and possibly contribute to the variability in fruit production, as well differences in the primary components that make up the final production figures. These variations can change a plant's morphological characteristics. Furthermore, plant injuries that naturally occur during crop management, fruit harvest, and other environmental variations, affect individual plant production during harvest (LÚCIO et al., 2006).

Other studies (CARPES et al., 2008; COUTO et al., 2009; LOPES et al., 1998; LORENTZ et al., 2005; LÚCIO et al., 2008) have reported that there is significant variability between crop rows and harvests, regardless of the crop grown, and that the variability significantly alters estimates of the sample size, sample type, size and shape of the plot, trial design and the number of plants needed to identify significant differences between treatments.

One alternative for evaluating the experimental area is the use of uniformity trials, where the area is entirely cultivated with a determined species and is subjected to identical cultural practices (MORAIS et al., 2014). Then the area is divided into small plots, in which the production of each plot is measured separately. This means that the plot outputs are similar to each other and can be added together to form plots of different shapes and sizes (STORCK et al., 2006). This type of experimental design allows the productive variability behavior to be identified.

Knowledge of production variability between experimental plots is needed because the relationship between basic units (BUs) is frequently disregarded or ignored. When randomness occurs between the BUs, it is possible to properly define the correct size and shape of the plots based in the homogeneity between the plots. It is important to identify which plot size generates randomness so that they are independent and do not interfere with the values of response variables, alter the estimates of experimental error, or affect the treatment effects. There have only been a few studies that have identified productivity behavior and observed 
probable environmental tendencies; such findings make it possible to reduce the experimental error and ensure that the results are more reliable when investigating experimental and crop management techniques.

The objective of this study was to characterize fruit production randomness between the basic units for pepper and snap beans.

\section{Material and Methods}

In this study, production data from uniformity trials were collected from a protected pepper and snap bean cultivation trial that was undertaken at the Crop Science Department at the Federal University of Santa Maria (UFSM). The site is located $29^{\circ} 43^{\prime}$ $23^{\prime \prime} \mathrm{S}$ and $53^{\circ} 43^{\prime} 15^{\prime \prime} \mathrm{W}$ and has an altitude of $95 \mathrm{~m}$. The climate in the region is classified as Cfa humid subtropical, without dry seasons and hot summers, as classified by KÖPPEN (MORENO, 1961). The soil is a red dystrophic sand-clay (Argissolo Vermelho Distrófico Arênico) soil (EMBRAPA, 1999).

Two pepper trials were conducted in a plastic greenhouse using the Vidi cultivar. The first trial took place during the summer-fall season and the second during spring-summer, 2001. Both consisted of 10 crop rows containing 70 plants, with each plant representing a basic unit (BU). There were five crop rows in the first season and four in the second.

The snap bean experiment used the Macarrão cultivar. There were two trials over two seasons. The first was in the fall-winter of 2009 and the second in spring-summer of 2009/2010. The first trial had three environmental treatments (greenhouse, plastic tunnel, and unprotected) and the second had two environmental treatments (plastic tunnel and unprotected). The greenhouse trial consisted of six rows of 72 plants, while the tunnel and unprotected crops consisted of six rows of 84 plants. In each trial, the BUs consisted of two plants, which made a total of $36 \mathrm{BUs}$ in the plastic greenhouse and $42 \mathrm{BU}$ in the plastic tunnel and unprotected environments.
Four harvests were carried out in the first trial and three in the second.

Fresh fruit biomass (FFB) data were collected over the course of the experiments. Different plot sizes were created in terms of the number of basic units and this was based on the number of plants available in a crop row. A sequence test was performed, based on the crop production data (COSTA NETO, 2002), to identify whether crop production differences between plots within a crop row, and between individuals and groups occurred randomly, that is to say, the production data could or could not occur by chance.

Data medians were calculated for each plot size and harvest grouping in order to form two data classes. Class 1 was formed by the elements below the median $(n)$ and class 2 contained the elements above the median $(m)$. These were represented by the symbols ".-" and "+", respectively. When the elements were the same as the median, these were included in class 1 .

The $n$ elements from class 1 and $m$ elements from class 2 were numbered as they occurred. The numbers of equal symbols preceded and followed by different or no symbols were used to determine the number of sequences, that is to say, the $C$ value.

When the number of plots per cultivated row was lower than 20, a least significant difference (LSD) was calculated, which was equal to twice the lowest value between $\alpha 1 \mathrm{p}(\mathrm{c} \leq \mathrm{c} 1)$ and $\alpha 2 \mathrm{p}(\mathrm{c} \geq \mathrm{c} 2)$, which were tabulated by the sequence test according to the number of elements above $m$ and below $n$ in relation to the median, and the number of sequences for observed $C$. The sequence was considered random when the LSD was higher than $5 \%$ and not random when it was lower than $5 \%$.

When the number of plots per line of cultivation was higher than 20, the test was performed using an approximation of the normal distribution using

$$
z=\frac{C-E(C)}{\sqrt{V(C)}}
$$


where $C$ is the number of sequences observed,

$$
\begin{array}{r}
E(C)=1+\frac{2 m n}{m+n}, \text { and } \\
V(C)=\frac{2 m n(2 m n-m-n)}{(m+n)^{2}(m+n-1)} .
\end{array}
$$

Data randomness was rejected if $\mathrm{z}>\left|\mathrm{z}_{\alpha / 2}\right|$ at the $5 \%$ probability level.

\section{Results and Discussion}

When the pepper crops were individually analyzed for spatial randomness in the crop row, the results showed that the plot sizes with fewer than seven basic units were spatially non-random in the row during the summer-fall and the spring-summer seasons (Table 1). This could be due to the large number of plants per crop row (70). A higher plot number may generate many sequence numbers, which improves the ability to determine whether there are any relationships between the BUs in a row. When there was no randomness between the plots in the row, a low number of sequences was obtained, which indicated that production was concentrated in certain, specific areas within the plastic greenhouse.

Table 1. Percentage of crop rows showing spatial randomness for different plot sizes and harvest groupings (HG) of pepper (Capsicum annuum) and snap beans (Phaseolus vulgaris) during different cultivation seasons in the plastic

\begin{tabular}{|c|c|c|c|c|c|c|c|c|}
\hline \multicolumn{9}{|c|}{ Pepper crop } \\
\hline & \multirow[b]{2}{*}{ HG } & \multicolumn{7}{|c|}{ Number of BUs/Plot } \\
\hline & & 1 & 2 & & & 7 & 10 & 14 \\
\hline \multirow{7}{*}{$\begin{array}{c}1^{\text {st }} \text { crop } \\
\text { Summer-Fall }\end{array}$} & Individuals & 92 & 86 & \multicolumn{2}{|c|}{92} & 100 & 100 & 100 \\
\hline & $1^{\text {st }}$ and $2^{\text {nd }}$ & 100 & 100 & \multicolumn{2}{|c|}{100} & 100 & 100 & 100 \\
\hline & $3^{\mathrm{rd}}, 4^{\text {th }}$ and $5^{\text {th }}$ & 100 & 80 & \multicolumn{2}{|c|}{80} & 90 & 100 & 100 \\
\hline & $1^{\text {st }}, 2^{\text {nd }}$, and $3^{\text {rd }}$ & 100 & 100 & \multicolumn{2}{|c|}{100} & 100 & 100 & 100 \\
\hline & $4^{\text {th }}$ and $5^{\text {th }}$ & 100 & 100 & \multicolumn{2}{|c|}{80} & 90 & 100 & 100 \\
\hline & $2^{\text {nd }}, 3^{\text {rd }}$, and $4^{\text {th }}$ & 80 & 100 & \multicolumn{2}{|c|}{100} & 100 & 100 & 100 \\
\hline & Total & 90 & 100 & \multicolumn{2}{|c|}{100} & 100 & 100 & 100 \\
\hline \multirow{5}{*}{$\begin{array}{c}2^{\text {nd }} \text { crop } \\
\text { Spring-Summer }\end{array}$} & Individuals & 92.5 & 92.5 & \multicolumn{2}{|c|}{92.5} & 90 & 100 & 100 \\
\hline & $1^{\text {st }}$ and $2^{\text {nd }}$ & 90 & 100 & \multicolumn{2}{|c|}{100} & 90 & 100 & 100 \\
\hline & $3^{\text {rd }}$ and $4^{\text {th }}$ & 90 & 100 & \multicolumn{2}{|c|}{90} & 90 & 100 & 100 \\
\hline & $2^{\text {nd }}$ and $3^{\text {rd }}$ & 100 & 90 & \multicolumn{2}{|c|}{100} & 90 & 100 & 100 \\
\hline & \multirow[t]{3}{*}{ Total } & 100 & 90 & \multicolumn{2}{|c|}{100} & 100 & 100 & 100 \\
\hline \multirow{2}{*}{\multicolumn{8}{|c|}{ Snap bean crop }} & \\
\hline & & & & \multicolumn{3}{|c|}{ Number of BUs/Plot } & & \\
\hline & $\mathrm{HG}$ & 1 & 2 & 3 & 4 & 6 & 9 & 12 \\
\hline \multirow{5}{*}{ Fall-Winter } & Individual & 83.33 & 95.83 & 100 & 91.66 & 100 & 100 & 100 \\
\hline & $1^{\text {st }}$ and $2^{\text {nd }}$ & 83.33 & 100 & 100 & 83.33 & 100 & 100 & 100 \\
\hline & $3^{\text {rd }}$ and $4^{\text {th }}$ & 100 & 100 & 100 & 100 & 100 & 100 & 100 \\
\hline & $2^{\text {nd }}$ and $3^{\text {rd }}$ & 83.33 & 100 & 100 & 83.33 & 100 & 100 & 100 \\
\hline & Total & 83.33 & 100 & 100 & 100 & 100 & 100 & 100 \\
\hline
\end{tabular}
greenhouse. 
Table 1 also shows that more randomness occurred in the first pepper harvest groupings and that there was no randomness between different plot sizes in the later harvest groupings. This observation corroborates Lopes et al. (1998) who reported that in tomato plants, the higher the percentage of harvested fruit: the higher is the heterogeneity between plots. After analyzing the first harvest group, the results showed that there was a decrease in the operating factors in the crop rows and a decrease in the experimental error. The BU formed by 10 and 14 plants in a line had a random FFB for all the harvest groups, which indicated that the use of bigger plots leads to homogeneity in a row.

As plant growth progressed and the number of harvests increased, non-casual factors appeared in the row productivity, making crop production behave differently from what was expected. This may be due to the decrease in soil fertility, differences in the humidity levels, injuries caused by harvest, differences in air temperature, etc. Previous researchers such as Couto et al. (2009); Lopes et al. (1998); Lorentz (2004); Lúcio et al. (2006); and Zanardo et al. (2010), also suggested these differences between the plots and the lack of production randomness between the plots in a row were due to natural and/or induced factors, which lead to an increase in experimental errors. This causes a reduction in experimental quality and different results from what was expected under ideal environmental conditions.

The simulated plot size results showed that there was lack of randomness in the plot sizes with one plant in the first cultivation trial and two plants in the second. The use of plots containing more than five BUs eliminated cases where reduced production was recorded. However, non-random crop rows occurred with up to seven BUs, which indicated that factors other than lack of production were causing a certain percentage of the crop rows to produce non-homogenously distributed FFP production values within a row. Generally, in the simulations containing 10 BUs and 14 BUs, the variation coefficient value began to stabilize (Table 2), and the lines showed random production behavior.

In the snap bean cultivation experiments in the plastic greenhouse, a tendency was observed in the fresh fruit biomass production values, especially in the crop rows formed by plots of one and four BUs. The plots with six or more BUs and 12 or more plants per plot did not show tendency formation problems within a row and their production was distributed regularly between the experimental units (Table 1).

In general, the plots in the plastic tunnel cultivation environment had a lower percentage of crop rows that showed non-randomness than the unprotected environment in fall-winter season (Table 3). In contrast to the plastic greenhouse cultivation, where there was non-randomness in the row at up to four BU per plot, the tunnel environment showed non-random fruit production between plots that consisted of up to three BUs. The results for the unprotected cultivation plots during the fall-winter season were different from the two other environments because of non-random lines in any simulation containing a basic unit size of up to three BU and in its harvest groupings (Table 3 ). In the same way as the plastic greenhouse, the results showed that in the plastic tunnel and for the unprotected cultivation experiment, production randomness in the cultivation lines was evident in plots with six or more BUs and 12 or more plants per plot. 
Table 2. Average, median (Med), standard deviation (SD), in grams; and the variation coefficient (VC\%) statistics for the spatial evaluation of pepper fruit (Capsicum annuum) fresh biomass in crop rows with plots containing different numbers of Basic Units (BUs) and harvest groupings (HG) in the plastic greenhouse for the Summer-Fall and SpringSummer seasons.

\begin{tabular}{|c|c|c|c|c|c|c|c|c|c|c|}
\hline \multicolumn{6}{|c|}{ Summer/Fall } & \multicolumn{5}{|c|}{ Spring/Summer } \\
\hline $\begin{array}{l}\text { Number } \\
\text { BUs/Plot }\end{array}$ & HG & Average & Med & SD & $\mathrm{VC} \%$ & HG & Average & Med & $\mathrm{SD}$ & $\mathrm{VC} \%$ \\
\hline \multirow{7}{*}{$1 \mathrm{BU}$} & Individual & 220 & 170 & 200 & 93.27 & Ind. & 310 & 270 & 290 & 92.76 \\
\hline & $1^{\text {st }}$ and $2^{\text {nd }}$ & 490 & 470 & 280 & 56.69 & $1^{\text {st }}$ and $2^{\text {nd }}$ & 740 & 750 & 420 & 56.15 \\
\hline & $3^{\text {rd }}, 4^{\text {th }}$, and $5^{\text {th }}$ & 600 & 590 & 330 & 54.65 & $3^{\text {rd }}$ and $4^{\text {th }}$ & 510 & 480 & 390 & 75.43 \\
\hline & $1^{\text {st }}, 2^{\text {nd }}$, and $3^{\text {rd }}$ & 740 & 740 & 320 & 43.92 & $2^{\text {nd }}$ and $3^{\text {rd }}$ & 700 & 690 & 450 & 63.82 \\
\hline & $4^{\text {th }}$ and $5^{\text {th }}$ & 350 & 320 & 280 & 78.98 & Total & 1260 & 1260 & 560 & 44.31 \\
\hline & $2^{\text {nd }}, 3^{\text {rd }}$, and $4^{\text {th }}$ & 700 & 700 & 310 & 44.39 & - & - & - & - & - \\
\hline & Total & 1090 & 1080 & 450 & 40.98 & - & - & - & - & - \\
\hline \multirow{7}{*}{$2 \mathrm{BUs}$} & Individual & 440 & 420 & 280 & 65.16 & Ind. & 630 & 580 & 430 & 68.51 \\
\hline & $1^{\text {st }}$ and $2^{\text {nd }}$ & 970 & 960 & 380 & 3958 & $1^{\text {st }}$ and $2^{\text {nd }}$ & 1490 & 1500 & 580 & 39.16 \\
\hline & $3^{\text {rd }}, 4^{\text {th }}$, and $5^{\text {th }}$ & 1200 & 1170 & 460 & 38.13 & $3^{\text {rd }}$ and $4^{\text {th }}$ & 1030 & 990 & 560 & 54.84 \\
\hline & $1^{\text {st }}, 2^{\text {nd }}$, and $3^{\text {rd }}$ & 1480 & 1470 & 460 & 31.31 & $2^{\text {nd }}$ and $3^{\text {rd }}$ & 740 & 690 & 490 & 65.87 \\
\hline & $4^{\text {th }}$ and $5^{\text {th }}$ & 700 & 680 & 400 & 56.63 & Total & 2520 & 2510 & 750 & 29.92 \\
\hline & $2^{\text {nd }}, 3^{\text {rd }}$, and $4^{\text {th }}$ & 1410 & 1390 & 440 & 31.30 & - & - & - & - & - \\
\hline & Total & 2180 & 2160 & 620 & 28.70 & - & - & - & - & - \\
\hline \multirow{7}{*}{$5 \mathrm{BUs}$} & Individual & 1090 & 1050 & 490 & 44.86 & Ind. & 1570 & 1510 & 700 & 44.37 \\
\hline & $1^{\text {st }}$ and $2^{\text {nd }}$ & 2430 & 2440 & 630 & 25.88 & $1^{\text {st }}$ and $2^{\text {nd }}$ & 3720 & 3680 & 900 & 24.16 \\
\hline & $3^{\text {rd }}, 4^{\text {th }}$, and $5^{\text {th }}$ & 3010 & 2940 & 750 & 24.80 & $3^{\text {rd }}$ and $4^{\text {th }}$ & 2570 & 2500 & 620 & 24.15 \\
\hline & $1^{\text {st }}, 2^{\text {nd }}$, and $3^{\text {rd }}$ & 3690 & 3710 & 750 & 20.22 & $2^{\text {nd }}$ and $3^{\text {rd }}$ & 1850 & 1760 & 810 & 43.55 \\
\hline & $4^{\text {th }}$ and $5^{\text {th }}$ & 1750 & 1690 & 660 & 37.88 & Total & 6290 & 6230 & 1170 & 18.63 \\
\hline & $2^{\text {nd }}, 3^{\text {rd }}$, and $4^{\text {th }}$ & 3510 & 3510 & 670 & 19.11 & - & - & - & - & - \\
\hline & Total & 5440 & 5360 & 1020 & 18.67 & - & - & - & - & - \\
\hline \multirow{7}{*}{$7 \mathrm{BUs}$} & Individual & 1520 & 1500 & 580 & 37.94 & Ind. & 2200 & 2150 & 860 & 39.04 \\
\hline & $1^{\text {st }}$ and $2^{\text {nd }}$ & 3400 & 3370 & 790 & 23.11 & $1^{\text {st }}$ and $2^{\text {nd }}$ & 5200 & 5110 & 1050 & 20.19 \\
\hline & $3^{\text {rd }}, 4^{\text {th }}$, and $5^{\text {th }}$ & 4220 & 4200 & 880 & 20.80 & $3^{\text {rd }}$ and $4^{\text {th }}$ & 3600 & 3530 & 1080 & 29.97 \\
\hline & $1^{\text {st }}, 2^{\text {nd }}$, and $3^{\text {rd }}$ & 5170 & 5200 & 900 & 17.45 & $2^{\text {nd }}$ and $3^{\text {rd }}$ & 2590 & 2550 & 930 & 35.92 \\
\hline & $4^{\text {th }}$ and $5^{\text {th }}$ & 2450 & 2360 & 820 & 33.57 & Total & 8810 & 8730 & 1300 & 14.74 \\
\hline & $2^{\text {nd }}, 3^{\text {rd }}$, and $4^{\text {th }}$ & 4920 & 4920 & 850 & 17.31 & - & - & - & - & - \\
\hline & Total & 7620 & 7530 & 1200 & 15.71 & - & - & - & - & - \\
\hline \multirow{7}{*}{$10 \mathrm{BUs}$} & Individual & 2180 & 2150 & 720 & 32.96 & Ind. & 3150 & 3080 & 1090 & 34.75 \\
\hline & $1^{\text {st }}$ and $2^{\text {nd }}$ & 4860 & 4780 & 890 & 18.33 & $1^{\text {st }}$ and $2^{\text {nd }}$ & 7430 & 7460 & 1340 & 17.97 \\
\hline & $3^{\text {rd }}, 4^{\text {th }}$, and $5^{\text {th }}$ & 6020 & 6100 & 1090 & 18.08 & $3^{\text {rd }}$ and $4^{\text {th }}$ & 5150 & 4930 & 1300 & 25.30 \\
\hline & $1^{\text {st }}, 2^{\text {nd }}$, and $3^{\text {rd }}$ & 7380 & 7400 & 950 & 12.93 & $2^{\text {nd }}$ and $3^{\text {rd }}$ & 3700 & 3600 & 1190 & 32.11 \\
\hline & $4^{\text {th }}$ and $5^{\text {th }}$ & 3510 & 3430 & 990 & 28.12 & Total & 12580 & 12320 & 1600 & 12.71 \\
\hline & $2^{\text {nd }}, 3^{\text {rd }}$, and $4^{\text {th }}$ & 7030 & 6900 & 970 & 13.83 & - & - & - & - & - \\
\hline & Total & 10890 & 10850 & 1300 & 11.95 & - & - & - & - & - \\
\hline \multirow{7}{*}{14 BUs } & Individual & 3050 & 2980 & 860 & 28.12 & Ind. & 4400 & 4380 & 1320 & 30.07 \\
\hline & $1^{\text {st }}$ and $2^{\text {nd }}$ & 6810 & 6740 & 1000 & 14.75 & $1^{\text {st }}$ and $2^{\text {nd }}$ & 10410 & 10630 & 1480 & 14.23 \\
\hline & $3^{\text {rd }}, 4^{\text {th }}$, and $5^{\text {th }}$ & 8430 & 8310 & 1410 & 16.77 & $3^{\text {rd }}$ and $4^{\text {th }}$ & 7210 & 6990 & 1540 & 21.42 \\
\hline & $1^{\text {st }}, 2^{\text {nd }}$, and $3^{\text {rd }}$ & 10330 & 10320 & 1080 & 10.46 & $2^{\text {nd }}$ and $3^{\text {rd }}$ & 5190 & 5080 & 1390 & 26.80 \\
\hline & $4^{\text {th }}$ and $5^{\text {th }}$ & 4910 & 4860 & 1380 & 28.06 & Total & 17610 & 17510 & 1780 & 10.09 \\
\hline & $2^{\text {nd }}, 3^{\text {rd }}$, and $4^{\text {th }}$ & 13210 & 12790 & 1460 & 11.03 & - & - & - & - & - \\
\hline & Total & 15240 & 14990 & 1600 & 10.52 & - & - & - & - & - \\
\hline
\end{tabular}


Table 3. Percentage of crop rows showing spatial randomness for different numbers of Basic Units (BUs)/crop and harvest groupings (HG) for snap bean (Phaseolus vulgaris) in the unprotected and plastic tunnel experiments during the Fall- Winter and Spring-Summer seasons.

\begin{tabular}{|c|c|c|c|c|c|c|c|}
\hline \multicolumn{8}{|c|}{ Fall/Winter crop } \\
\hline & \multirow[b]{2}{*}{ HG } & \multicolumn{5}{|c|}{ Number of BUs/Crop } & \multirow[b]{2}{*}{14} \\
\hline & & 1 & 2 & 3 & 6 & 7 & \\
\hline \multirow{5}{*}{ Unprotected } & Individual & 58.33 & 75 & 75 & 100 & 100 & 100 \\
\hline & $1^{\text {st }}$ and $2^{\text {nd }}$ & 66.66 & 66.66 & 66.66 & 100 & 100 & 100 \\
\hline & $3^{\text {rd }}$ and $4^{\text {th }}$ & 100 & 66.66 & 66.66 & 100 & 100 & 100 \\
\hline & $2^{\text {nd }}$ and $3^{\text {rd }}$ & 66.66 & 33.33 & 66.66 & 100 & 100 & 100 \\
\hline & Total & 66.66 & 33.33 & 66.66 & 100 & 100 & 100 \\
\hline \multirow{5}{*}{ Tunnel } & Individual & 91.66 & 100 & 91.66 & 100 & 100 & 100 \\
\hline & $1^{\text {st }}$ and $2^{\text {nd }}$ & 100 & 100 & 100 & 100 & 100 & 100 \\
\hline & $3^{\text {rd }}$ and $4^{\text {th }}$ & 100 & 100 & 100 & 100 & 100 & 100 \\
\hline & $2^{\text {nd }}$ and $3^{\text {rd }}$ & 100 & 100 & 100 & 100 & 100 & 100 \\
\hline & Total & 66.66 & 100 & 100 & 100 & 100 & 100 \\
\hline \multicolumn{8}{|c|}{ Spring/Summer crop } \\
\hline & & \multicolumn{5}{|c|}{ Number of BUs/Crop } & \\
\hline & HG & 1 & 2 & 3 & 6 & 7 & 14 \\
\hline \multirow{4}{*}{ Unprotected } & Individual & 77.77 & 66.66 & 77.77 & 100 & 100 & 100 \\
\hline & $1^{\text {st }}$ and $2^{\text {nd }}$ & 100 & 66.66 & 100 & 100 & 100 & 100 \\
\hline & $2^{\text {nd }}$ and $3^{\text {rd }}$ & 100 & 66.66 & 66.66 & 100 & 100 & 100 \\
\hline & Total & 100 & 100 & 100 & 100 & 100 & 100 \\
\hline \multirow{4}{*}{ Tunnel } & Individual & 77.77 & 66.66 & 77.77 & 100 & 100 & 100 \\
\hline & $1^{\text {st }}$ and $2^{\text {nd }}$ & 100 & 100 & 100 & 100 & 100 & 100 \\
\hline & $2^{\text {nd }}$ and $3^{\text {rd }}$ & 66.66 & 100 & 66.66 & 100 & 100 & 100 \\
\hline & Total & 100 & 100 & 100 & 100 & 100 & 100 \\
\hline
\end{tabular}

The differences were more evident between the plastic tunnel and the unprotected cultivation trial in fall-winter season than in spring-summer, where the environments were more similar with regard to variability between crop rows in each plot. In the unprotected cultivation experiment in the springsummer season, there was a reduction in the lack of randomness within the different basic unit sizes when grouping the first harvests (Table 3). The two cultivation periods produced similar behavioral results in all three environments in that there were more non-random lines as the size of the basic unit decreased.

Haesbaert et al. (2011), who studied snap bean, suggested that there were disadvantages in analyzing the crops individually instead of as a whole because with groupings there is an increase in the average and, consequently, a reduction of the variation coefficient ( $\mathrm{VC} \%$ ), which leads to lower variability and higher precision. This corroborates with what was observed in this study, which suggests that besides the use of larger experimental units, the experiment should also contain groupings that represent more intensive harvests, since these groupings tend to not show any tendencies and have less crop row variability.

The descriptive data analysis did not identify any relationships between the non-random crop rows during cultivation, and the season and growth environments. However, the variation coefficients of the unprotected cultivation treatment were superior to those derived from the plastic tunnel data, and from any of the harvest grouping data. This was because the expected reduction in $\mathrm{VC} \%$ was less pronounced in the unprotected environment (Tables 4 and 5). This variability in the 
unprotected cultivation $\mathrm{VC} \%$ probably led to the increase in the percentage of crop rows with nonrandom sequences, in terms of plot sizes and harvest groupings, compared to the plastic tunnel. According to Andriolo (2002), cultivations in the field are exposed to environmental variations because there is less control over temperature, humidity, and wind, compared to covered conditions where it is easier to control these factors. Therefore, there is a greater possibility non-randomness occurring in crop rows subjected to unprotected cultivation.

Table 4. Average, median (Med), standard deviation (SD), in grams; and the variation coefficient (VC\%) statistics for the spatial evaluation of snap bean fruit (Phaseolus vulgaris) fresh biomass in crop rows with plots containing different numbers of Basic Units (BUs) and harvest groupings (HG) in the plastic greenhouse during the Fall-Winter season.

\begin{tabular}{|c|c|c|c|c|c|}
\hline Number of BUs/Crop & $\mathrm{HG}$ & Average & Med & $\mathrm{SD}$ & $\mathrm{VC} \%$ \\
\hline \multirow{5}{*}{$1 \mathrm{BU}$} & Individual & 138.29 & 119.57 & 96.02 & 69.43 \\
\hline & $1^{\text {st }}$ and $2^{\text {nd }}$ & 301.91 & 283.35 & 175.47 & 58.12 \\
\hline & $3^{\text {rd }}$ and $4^{\text {th }}$ & 251.26 & 234.95 & 143.72 & 57.20 \\
\hline & $2^{\text {nd }}$ and $3^{\text {rd }}$ & 379.33 & 364.49 & 195.47 & 51.53 \\
\hline & Total & 553.17 & 558.86 & 258.90 & 46.80 \\
\hline \multirow{5}{*}{$2 \mathrm{BUs}$} & Individual & 276.58 & 258.18 & 135.48 & 48.98 \\
\hline & $1^{\text {st }}$ and $2^{\text {nd }}$ & 603.81 & 613.92 & 243.69 & 40.36 \\
\hline & $3^{\text {rd }}$ and $4^{\text {th }}$ & 502.52 & 474.28 & 199.31 & 39.66 \\
\hline & $2^{\text {nd }}$ and $3^{\text {rd }}$ & 758.65 & 731.26 & 265.20 & 34.96 \\
\hline & Total & 1106.34 & 1060.37 & 340.94 & 30.82 \\
\hline \multirow{5}{*}{$3 \mathrm{BUs}$} & Individual & 414.88 & 405.21 & 165.29 & 39.84 \\
\hline & $1^{\text {st }}$ and $2^{\text {nd }}$ & 905.72 & 908.36 & 290.51 & 32.08 \\
\hline & $3^{\text {rd }}$ and $4^{\text {th }}$ & 753.79 & 713.45 & 251.83 & 33.41 \\
\hline & $2^{\text {nd }}$ and $3^{\text {rd }}$ & 1137,98 & 1120.15 & 313.48 & 27.55 \\
\hline & Total & 1659.51 & 1639.78 & 387.41 & 23.34 \\
\hline \multirow{5}{*}{$4 \mathrm{BUs}$} & Individual & 553.17 & 529.61 & 208.08 & 37.62 \\
\hline & $1^{\text {st }}$ and $2^{\text {nd }}$ & 1207,63 & 1149.41 & 361.04 & 29.90 \\
\hline & $3^{\text {rd }}$ and $4^{\text {th }}$ & 1005.05 & 980.81 & 312.83 & 31.13 \\
\hline & $2^{\text {nd }}$ and $3^{\text {rd }}$ & 1517.31 & 1469.59 & 407.25 & 26.84 \\
\hline & Total & 2212.68 & 2106.73 & 491.83 & 22.23 \\
\hline \multirow{5}{*}{$6 \mathrm{BUs}$} & Individual & 829.75 & 810.19 & 274.57 & 33.09 \\
\hline & $1^{\text {st }}$ and $2^{\text {nd }}$ & 1811.44 & 1833.92 & 479.17 & 26.45 \\
\hline & $3^{\text {rd }}$ and $4^{\text {th }}$ & 1507.57 & 1447.21 & 434.30 & 28.81 \\
\hline & $2^{\text {nd }}$ and $3^{\text {rd }}$ & 2275.96 & 2242.04 & 518.99 & 22.80 \\
\hline & Total & 3319.01 & 3288.47 & 619.94 & 18.68 \\
\hline \multirow{5}{*}{9 BUs } & Individual & 1244.63 & 1225.72 & 330.41 & 26.55 \\
\hline & $1^{\text {st }}$ and $2^{\text {nd }}$ & 2717.16 & 2621.23 & 576.23 & 21.21 \\
\hline & $3^{\text {rd }}$ and $4^{\text {th }}$ & 2261.36 & 2264.71 & 526.49 & 23.28 \\
\hline & $2^{\text {nd }}$ and $3^{\text {rd }}$ & 3413.94 & 3382.82 & 552.43 & 16.18 \\
\hline & Total & 4978.52 & 4937.67 & 711.68 & 14.30 \\
\hline \multirow{5}{*}{$12 \mathrm{BUs}$} & Individual & 1659.51 & 1638.61 & 368.74 & 22.22 \\
\hline & $1^{\text {st }}$ and $2^{\text {nd }}$ & 3622.88 & 3515.89 & 445.10 & 12.29 \\
\hline & $3^{\text {rd }}$ and $4^{\text {th }}$ & 3015.15 & 2947.61 & 693.67 & 23.01 \\
\hline & $2^{\text {nd }}$ and $3^{\text {rd }}$ & 4551.92 & 4428.91 & 606.54 & 13.32 \\
\hline & Total & 6638.03 & 6680.00 & 791.89 & 11.93 \\
\hline
\end{tabular}


Table 5. Average, median (Med), standard deviation (SD), in grams; and the variation coefficient (VC\%) statistics for the spatial evaluation of snap bean fruit (Phaseolus vulgaris) fresh biomass in crop rows with plots containing different numbers of Basic Units (BUs) and harvest groupings (HG) in the unprotected and plastic tunnel experiments during the Fall-Winter and Spring-Summer seasons.

\begin{tabular}{|c|c|c|c|c|c|c|c|c|c|}
\hline \multirow{2}{*}{$\begin{array}{l}\text { Number of BU/ } \\
\text { Crop }\end{array}$} & \multirow[b]{2}{*}{ HG } & \multicolumn{4}{|c|}{ Unprotected (Fall-Winter) } & \multicolumn{4}{|c|}{ Unprotected (Spring-Summer) } \\
\hline & & Average & Med & SD & $\% \mathrm{VC}$ & Average & Med & SD & $\% \mathrm{VC}$ \\
\hline \multirow{5}{*}{$1 \mathrm{BU}$} & Individual & 160.90 & 152.13 & 89.03 & 55.33 & 313.66 & 299.41 & 162.61 & 51.84 \\
\hline & $1^{\text {st }}$ and $2^{\text {nd }}$ & 376.86 & 362.78 & 179.26 & 47.57 & 677.75 & 708.75 & 290.04 & 42.79 \\
\hline & $3^{\text {rd }}$ and $4^{\text {th }}$ & 266.74 & 253.76 & 117.68 & 44.12 & - & - & - & - \\
\hline & $2^{\text {nd }}$ and $3^{\text {rd }}$ & 458.19 & 450.97 & 215.68 & 47.07 & 788.81 & 787.42 & 316.81 & 40.16 \\
\hline & Total & 643.60 & 635.68 & 260.13 & 40.42 & 940.97 & 952.60 & 348.29 & 37.01 \\
\hline \multirow{5}{*}{2 BUs } & Individual & 321.80 & 321.47 & 137.25 & 42.65 & 627.31 & 606.49 & 244.62 & 38.99 \\
\hline & $1^{\text {st }}$ and $2^{\text {nd }}$ & 753.73 & 758.06 & 288.96 & 38.34 & 1355.49 & 1397.33 & 398.18 & 29.37 \\
\hline & $3^{\text {rd }}$ and $4^{\text {th }}$ & 533.47 & 525.03 & 171.65 & 32.18 & - & - & - & - \\
\hline & $2^{\text {nd }}$ and $3^{\text {rd }}$ & 916.38 & 935.46 & 346.57 & 37.82 & 1577.61 & 1482.45 & 465.57 & 29.51 \\
\hline & Total & 1287.20 & 1312.14 & 424.10 & 32.95 & 1881.93 & 1885.44 & 458.61 & 24.37 \\
\hline \multirow{5}{*}{$3 \mathrm{BUs}$} & Individual & 482.70 & 481.70 & 187.03 & 38.75 & 940.97 & 894.00 & 324.56 & 34.49 \\
\hline & $1^{\text {st }}$ and $2^{\text {nd }}$ & 1130.59 & 1155.43 & 402.41 & 35.59 & 2033.24 & 2006.21 & 523.15 & 25.73 \\
\hline & $3^{\text {rd }}$ and $4^{\text {th }}$ & 800.21 & 780.21 & 246.53 & 30.81 & - & - & - & - \\
\hline & $2^{\text {nd }}$ and $3^{\text {rd }}$ & 1374.58 & 1411.03 & 502.36 & 36.55 & 2366.42 & 2299.01 & 583.76 & 24.67 \\
\hline & Total & 1930.80 & 1996.44 & 611.79 & 31.69 & 2822.90 & 2777.77 & 571.09 & 20.23 \\
\hline \multirow{5}{*}{$6 \mathrm{BUs}$} & Individual & 965.40 & 988.62 & 318.54 & 33.00 & 1881.93 & 1854.66 & 558.31 & 29.67 \\
\hline & $1^{\text {st }}$ and $2^{\text {nd }}$ & 2261.19 & 2508.72 & 731.16 & 32.34 & 4066.48 & 3942.69 & 866.62 & 21.31 \\
\hline & $3^{\text {rd }}$ and $4^{\text {th }}$ & 1600.42 & 1653.96 & 388.54 & 24.28 & - & - & - & - \\
\hline & $2^{\text {nd }}$ and $3^{\text {rd }}$ & 2749.15 & 3017.73 & 893.93 & 32.52 & 4732.83 & 4756.11 & 1032.88 & 21.82 \\
\hline & Total & 3861.61 & 4132.64 & 1088.24 & 28.18 & 5645.79 & 5641.28 & 982.28 & 17.40 \\
\hline \multirow{5}{*}{7 BUs } & Individual & 1126.30 & 1116.13 & 351.91 & 31.24 & 2195.59 & 2109.03 & 608.76 & 27.73 \\
\hline & $1^{\text {st }}$ and $2^{\text {nd }}$ & 2638.05 & 2723.51 & 807.79 & 30.62 & 4744.22 & 4811.00 & 947.95 & 19.98 \\
\hline & $3^{\text {rd }}$ and $4^{\text {th }}$ & 1867.16 & 1908.03 & 430.22 & 23.04 & - & - & - & - \\
\hline & $2^{\text {nd }}$ and $3^{\text {rd }}$ & 3207.34 & 3240.08 & 1007.86 & 31.42 & 5521.64 & 5364.86 & 1121.53 & 20.31 \\
\hline & Total & 4505.21 & 4634.50 & 1216.49 & 27.00 & 6586.76 & 6352.96 & 1069.24 & 16.23 \\
\hline \multirow{6}{*}{14 BUs } & Individual & 2252.60 & 2322.19 & 644.24 & 28.60 & 4391.17 & 4240.06 & 957.69 & 21.81 \\
\hline & $1^{\text {st }}$ and $2^{\text {nd }}$ & 5276.10 & 5417.30 & 1507.55 & 28.57 & 9488.45 & 9071.31 & 1312.55 & 13.83 \\
\hline & $3^{\text {rd }}$ and $4^{\text {th }}$ & 3734.32 & 3994.49 & 823.14 & 22.04 & - & - & - & - \\
\hline & $2^{\text {nd }}$ and $3^{\text {rd }}$ & 6414.69 & 6698.88 & 1918.50 & 29.91 & 11043.27 & 11258.35 & 1823.87 & 16.52 \\
\hline & Total & 9010.42 & 9411.79 & 2297.61 & 25.50 & 13173.52 & 13219.71 & 1646.84 & 12.50 \\
\hline & & \multicolumn{4}{|c|}{ Plastic tunnel (Fall-Winter) } & \multicolumn{4}{|c|}{ Plastic tunnel (Spring-Summer) } \\
\hline \multirow{5}{*}{$1 \mathrm{BU}$} & Individual & 211.59 & 202.80 & 105.41 & 49.82 & 343.56 & 345.39 & 163.80 & 47.68 \\
\hline & $1^{\text {st }}$ and $2^{\text {nd }}$ & 574.22 & 565.56 & 194.47 & 33.87 & 986.68 & 959.98 & 338.07 & 34.26 \\
\hline & $3^{\text {rd }}$ and $4^{\text {th }}$ & 272.14 & 246.44 & 140.02 & 51.45 & - & - & - & - \\
\hline & $2^{\text {nd }}$ and $3^{\text {rd }}$ & 537.55 & 532.93 & 196.80 & 36.61 & 477.97 & 461.78 & 198.89 & 41.61 \\
\hline & Total & 846.36 & 833.56 & 269.84 & 31.88 & 1030.67 & 1011.10 & 342.02 & 33.18 \\
\hline \multirow{7}{*}{$2 \mathrm{BUs}$} & Individual & 423.18 & 434.50 & 150.36 & 35.53 & 687.11 & 704.39 & 245.02 & 35.66 \\
\hline & $1^{\text {st }}$ and $2^{\text {nd }}$ & 1148.43 & 1168.17 & 271.39 & 23.63 & 1973.36 & 1941.15 & 435.02 & 22.04 \\
\hline & $3^{\text {rd }}$ and $4^{\text {th }}$ & 544.29 & 508.64 & 191.74 & 35.23 & - & - & - & - \\
\hline & $2^{\text {nd }}$ and $3^{\text {rd }}$ & 1075.10 & 1091.12 & 254.30 & 23.65 & 955.93 & 944.39 & 290.18 & 30.36 \\
\hline & Total & 1692.72 & 1671.91 & 340.36 & 20.11 & 2061.34 & 2026.42 & 436.02 & 21.15 \\
\hline & Individual & 634.77 & 644.77 & 194.03 & 30.57 & 1030.67 & 1062.44 & 316.46 & 30.70 \\
\hline & $1^{\text {st }}$ and $2^{\text {nd }}$ & 1722.65 & 1726.73 & 332.01 & 19.27 & 2960.04 & 3010.75 & 493.69 & 16.68 \\
\hline
\end{tabular}


continuation

\begin{tabular}{|c|c|c|c|c|c|c|c|c|c|}
\hline \multirow[t]{3}{*}{$3 \mathrm{BUs}$} & $3^{\text {rd }}$ and $4^{\text {th }}$ & 816.43 & 821.04 & 254.23 & 31.14 & - & - & - & - \\
\hline & $2^{\text {nd }}$ and $3^{\text {rd }}$ & 1612.64 & 1651.25 & 278.22 & 17.25 & 1433.90 & 1444.58 & 371.18 & 25.89 \\
\hline & Total & 2539.08 & 2534.66 & 370.78 & 14.60 & 3092.01 & 3142.41 & 495.64 & 16.03 \\
\hline \multirow{5}{*}{6 BUs } & Individual & 1269.54 & 1300.90 & 297.41 & 23.43 & 2061.34 & 2095.29 & 502.87 & 24.40 \\
\hline & $1^{\text {st }}$ and $2^{\text {nd }}$ & 3445.30 & 3603.23 & 531.02 & 15.41 & 5920.08 & 5990.40 & 658.38 & 11.12 \\
\hline & $3^{\text {rd }}$ and $4^{\text {th }}$ & 1632.87 & 1576.57 & 378.97 & 23.21 & - & - & - & - \\
\hline & $2^{\text {nd }}$ and $3^{\text {rd }}$ & 3225.29 & 3386.52 & 441.32 & 13.68 & 2867.79 & 2864.20 & 609.01 & 21.24 \\
\hline & Total & 5078.17 & 5024.95 & 573.67 & 11.30 & 6184.03 & 6167.15 & 680.18 & 11.00 \\
\hline \multirow{5}{*}{$7 \mathrm{BUs}$} & Individual & 1481.13 & 1480.90 & 313.85 & 21.19 & 2404.90 & 2460.08 & 575.13 & 23.92 \\
\hline & $1^{\text {st }}$ and $2^{\text {nd }}$ & 4019.52 & 4094.48 & 548.84 & 13.65 & 6906.76 & 6902.52 & 656.54 & 9.51 \\
\hline & $3^{\text {rd }}$ and $4^{\text {th }}$ & 1905.01 & 1792.92 & 341.95 & 17.95 & - & - & - & - \\
\hline & $2^{\text {nd }}$ and $3^{\text {rd }}$ & 3762.83 & 3934.22 & 508.54 & 13.51 & 3345.76 & 3462.46 & 751.80 & 22.47 \\
\hline & Total & 5924.53 & 5884.32 & 627.38 & 10.59 & 7214.70 & 7252.05 & 664.93 & 9.22 \\
\hline \multirow{5}{*}{$14 \mathrm{BUs}$} & Individual & 2962.26 & 3029.64 & 480.03 & 16.20 & 4809.80 & 4941.50 & 774.53 & 16.10 \\
\hline & $1^{\text {st }}$ and $2^{\text {nd }}$ & 8039.03 & 8265.33 & 820.28 & 10.20 & 13813.53 & 14092.74 & 955.25 & 6.92 \\
\hline & $3^{\text {rd }}$ and $4^{\text {th }}$ & 3810.02 & 3775.35 & 401.36 & 10.53 & - & - & - & - \\
\hline & $2^{\text {nd }}$ and $3^{\text {rd }}$ & 7525.67 & 7577.14 & 585.16 & 7.78 & 6691.52 & 6929.84 & 966.34 & 14.44 \\
\hline & Total & 11849.05 & 12042.82 & 542.66 & 4.58 & 14429.40 & 14594.88 & 1010.02 & 7.00 \\
\hline
\end{tabular}

\section{Conclusions}

The use of ten plants per plot in the pepper trial was enough ensure that the crop rows produced results for fresh fruit biomass production that were entirely random. Classifying data into harvest groupings also produced more random data.

In the snap bean plastic greenhouse, plastic tunnel, and unprotected cultivation trials, the use of plots with six or more basic units and 12 or more plants per plot meant that the fresh fruit biomass production values within a crop row were random.

\section{References}

ANDRIOLO, J. L. Olericultura geral: princípios e técnicas. Santa Maria: UFSM, 2002. 158 p.

CARPES, R. H.; LÚCIO, A. D.; STORCK, L.; LOPES, S. J.; ZANARDO, B.; PALUDO, A. L. Ausência de frutos colhidos e suas interferências na variabilidade da fitomassa de frutos de abobrinha italiana cultivada em diferentes sistemas de irrigação. Revista Ceres, Viçosa, MG, v. 55, n. 6, p. 590-595, 2008.

COSTA NETO, P. L. O. Estatística. 2. ed. São Paulo: Edgard Blücher, 2002. 266 p.
COUTO, M. R. M.; LUCIO, A. D.; LOPES, S. J.; CARPES, R.H. Transformação de dados em experimentos com abobrinha italiana em ambiente protegido. Ciência Rural, Santa Maria, v. 39, n. 6, p. 1701-1707, 2009.

EMPRESA BRASILEIRA DE PESQUISA AGROPECUÁRIA - EMBRAPA. Centro Nacional de Pesquisa de Solos. Sistema Brasileiro de Classificação de Solos. Brasília: Embrapa, 1999. 412 p.

FACCO, G.; CARGNELUTTI FILHO, A.; LÚCIO, A. D.; SANTOS, G. O.; STEFANELLO, R. B.; ALVES, B. M.; BURIN, C.; NEU, I. M. M.; KLEINPAUL, J. A. Sample size for morphological traits of pigeonpea. Semina: Ciências Agrárias, Londrina, v. 36, n. 6, p. 4151-4164, 2015.

HAESBAERT, F. M.; SANTOS, D.; LUCIO, A. D.; BENZ, V.; ANTONELlO, B. I.; RIBEIRO, A. L. P. Tamanho de amostra para experimentos com feijão-devagem em diferentes ambientes. Ciência Rural, Santa Maria, v. 41, n. 1, p. 38-44, 2011.

LOPES, S. J.; STORCK, L.; HELDWEIN, A. B.; FEIJO, S.; ROS, C. A. Técnicas experimentais para tomateiro tipo salada sob estufas plásticas. Ciência Rural, Santa Maria, v. 28, n. 2, p. 193-197, 1998.

LORENTZ, L. H. Variabilidade da produção de frutos de pimentão em estufa plástica, relacionada com técnicas experimentais. 2004. Dissertação (Mestrado em Agronomia) - Universidade Federal de Santa Maria, Santa Maria. 
LORENTZ, L. H.; LUCIO, A. D.; BOLIGON, A. A.; LOPES, S. J.; STORCK, L. Variabilidade da produção de frutos de pimentão em estufa plástica. Ciência Rural, Santa Maria, v. 35, n. 2, p. 316-323, 2005.

LÚCIO, A. D.; CARPES, R. H.; STORCK, L.; LOPES, S. J.; LORENTZ, L. H.; PALUDO, A. L. Variância e média da massa de frutos de abobrinha-italiana em múltiplas colheitas. Horticultura Brasileira, Brasília, v. 26, n. 3, p. 335-341, 2008.

LÚCIO, A. D.; LORENTZ, L. H.; BOLIGON, A. A.; LOPES, S. J.; STORCK, L.; CARPES, R. H. Variação temporal da produção de pimentão influenciada pela posição e características morfológicas das plantas em ambiente protegido. Horticultura Brasileira, Brasília, v. 24, n. 1, p. 31-35, 2006.

MELO, P. C. T.; VILELA, N. J. Importância da cadeia produtiva brasileira de hortaliças. In: REUNIÃO ORDINÁRIA DA CÂMARA SETORIAL DA CADEIA PRODUTIVA DE HORTALIÇAS, 13., 2007, Brasília. Palestra... Brasília: MAPA, 2007. Disponível em: $<$ http://www.abhorticultura.com.br/downloads/cadeia produtiva.pdf $>$. Acesso em: 12 maio 2012.
MORAIS, A. R.; ARAÚJO, A. G.; PASQUAL, M.; PEIXOTO, A. P. B. Estimação do tamanho de parcela para experimentos com cultura de tecidos em videira. Semina: Ciências Agrárias, Londrina, v. 5, n. 1, p. 113124, 2014.

MORENO, J. A. Clima no Rio Grande do Sul. Porto Alegre: Secretaria da Agricultura, 1961. $41 \mathrm{p}$.

STEEL, R. G. D.; TORRIE, J. H.; DICKEY, D. A. Principles and procedures of statistics: a biometrical approach. New York: McGraw-Hill, 1997. 666 p.

STORCK, L.; GARCIA, D. C.; LOPES, S. J.; ESTEFANEL, V. Experimentação vegetal. Santa Maria: Ed. UFSM, 2006. 198 p.

ZANARDO, B.; LUCIO, A. D.; PALUDO, A. L.; SANTOS, D.; BENZ, V. Posições das mudas de alface nas bandejas de poliestireno e efeitos na normalidade e homogeneidade dos erros na produção de plantas. Revista Ciência Agronômica, Fortaleza, v. 41, n. 2, p. 285-293, 2010 
